\title{
Tissue Engineering of Skeletal Muscle
}

\author{
Klumpp Dorothee, Horch Raymund E. and Beier Justus P. \\ Department of Plastic and Hand Surgery, University Hospital of Erlangen-Nürnberg
}

Germany

\section{Introduction}

\subsection{Has Churchill been right?}

"Fifty years hence, we shall escape the absurdity of growing a whole chicken in order to eat the breast or wing, by growing these parts separately under a suitable medium" (Churchill 1932)

In 1932, Sir Winston Churchill predicted that it will be possible in future to grow and engineer muscle tissue in vitro. As a confirmation of his prediction, Vandenburgh et al. observed contracting muscle tissue engineered in vitro for the first time in 1988 (Vandenburgh, H.H. et al. 1988). Only one year later - in 1989 - the group showed that mechanical stimulation of embrionic myoblasts in vitro facilitates longitudinal growth of engineered skeletal muscle tissue (Vandenburgh, H.H. \& Karlisch 1989). This rapid development raised high expectations for future clinical applications of tissue engineering (TE) of skeletal muscle. Indeed, engineered muscle tissue could be used in a wide range of clinical situations.

A frequent clinical application of skeletal muscle tissue is the microsurgical transfer of myocutaneous free flaps for the coverage of soft tissue defects. As one major disadvantage, the use of free flaps is inevitably linked with a certain morbidity at the donor site including the loss of functional muscle tissue. In this situation, engineered muscle tissue could help to reduce the donor site morbidity. Above all, the advantage of muscle TE lies in the generation of functioning muscle tissue to replace certain muscles after damage or denervation (Klumpp et al. 2010). For example, the treatment of facial nerve palsy is momentarily limited to the transfer of autologous muscle tissue innervated by another nerve (the trigeminus nerve, e.g.) or free transfer of distant muscle tissue (Terzis \& Konofaos 2008). Though multiple techniques and modifications exist, the results yielded in those clinical situations are moderate (Kumar \& Hassan 2002, Terzis \& Noah 1997). Furthermore, Kim et al demonstrated that myoblast transplantation is a promising method for the reconstruction after partial glossectomy (Kim, J. et al. 2003). Herein, TE of skeletal muscle for the replacement of functional muscle tissue could offer an individual alternative.

However, a clinical application of skeletal muscle TE has not been realized to date due to certain obstacles which will be discussed in the following. Though, in vitro engineered tissue of skeletal muscle could already play an important role for the clinical treatment of inborn muscle diseases as well as muscle injuries. Once again, Vandenburgh and co-workers engineered dystrophic muscle tissue using it as drug screening platform for Duchenne muscular dystrophy (DMD) treatment (Vandenburgh, H. et al. 2009). Thus, a wide range of possible drugs can be analyzed without using time-consuming and costly in vivo models (Vandenburgh, H.). Vandenburgh's study demonstrates an economic approach for drug 
screening in general and orphan drugs in particular. Beside the relatively rare musculoskeletal disorders, engineered skeletal muscle also enables the analysis of more frequent diseases. Kaji et al introduced an in vitro model of electrically stimulated and contracting muscle tissue to analyze the insulin- and exercise-dependant glucose uptake which plays a role in insulin resistance of type 2 diabetics (Kaji et al.). Thus, skeletal muscle TE already plays a role for clinical treatments, though a direct bench-to-bedside approach has yet to become reality.

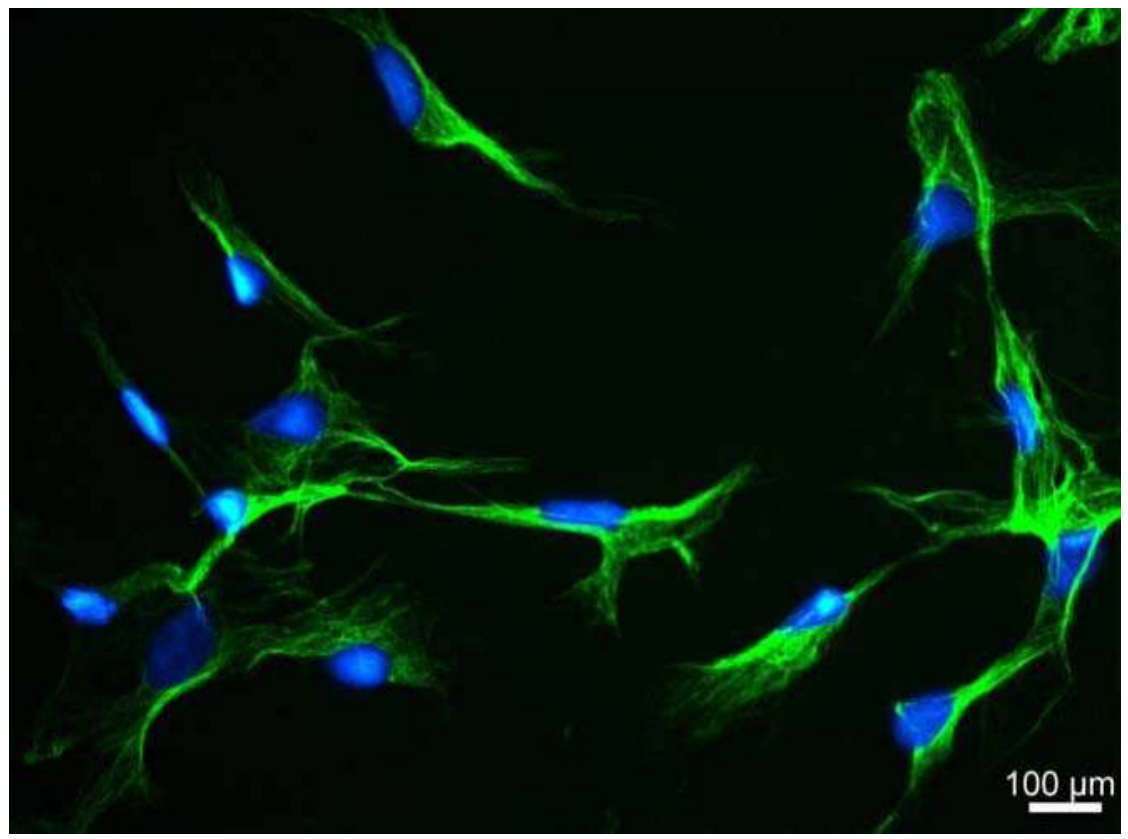

Fig. 1. Skeletal muscle precursor cells (myoblasts) in vitro. Immunofluorescent staining for desmin (green) an intermediate filament specifically expressed in myogenic differentiation prior to the formation of myotubes and fusion into muscle fibers. Nuclei are stained nonspecifically with DAPI (Diamidine-phenylindole-dihydrochloride; blue). Magnification 400x

\section{Finding the matrix for muscle TE}

\subsection{Materials}

A variety of materials has been analyzed and reviewed regarding their suitability for skeletal muscle TE. On one side, natural materials like collagen I in the first place are preferred due to their biocompatibility and their close resemblance to the natural extracellular matrix (ECM). On the other side, synthetic materials generally show greater stability as well as cost-saving and easy handling.

Regarding collagen I - the main component of the natural ECM of mature skeletal muscle tissue - its advantage lies in high elasticity which is a pre-requisite for muscle contraction. Thus, its mechanical properties in vivo meet the demands for new skeletal muscle tissue perfectly. Furthermore, bovine as well as avian collagen show very low immunogenicity in vitro and can be safely used in vivo (Peng et al. 2010). Therefore, collagen sponges and gels 
have been studied in vitro (Madaghiele et al. 2008) and in vivo (Kroehne et al. 2008). However, the rapid shrinkage of hydrogels in vitro as well as the low stability of collagen I are important disadvantages (Beier et al. 2009) and limit its use in long-term experiments. Another material frequently used for tissue engineering in vitro and in vivo is fibrin. The stability of fibrin gel is dependent on the concentration of fibrinogen and thrombin and can be augmented by addition of aprotinin which inhibits fibrinolysis (Meinhart et al. 1999). In addition, fibrin is known to accelerate vessel ingrowth into the matrix in vivo due to its binding sites for vascular endothelial growth factors (VEGF), fibroblast growth factor (FGF2) and the cytokine interleukin-1 (IL-1) (Mosesson 2005). Still, fibrin gels show a definite loss of stability after 4 weeks in vivo (Arkudas et al. 2009). As an exception to the relative instability of natural polymers, silkworm fibroin, the structure protein of silk, shows an astonishing tensile strength of $100-300 \mathrm{MPa}$ and stability (Zhao et al. 2003). An in vivo stability of over 1 year has been reported for $17 \%$ fibroin concentration but, the cell-toxic HFIP (hexafluoro-iso-propanol) as organic solvent is necessary. Even in all-aqueous dissolution of silk fibroin with concentrations of 6 to $10 \%$ fibroin, the in vivo stability has been found to range between 2 and 6 months (Wang, Y. et al. 2008). Thus, silk fibroin provides an adequate stability for tissue engineering in vivo. Additionally, silk is in clinical use as suture material for a long time. However, hypersensitivity and adverse reactions have been reported and put the biocompatibility of silk into question (Soong \& Kenyon 1984). The chemical and immunogenic properties of silk of Bombyx mori silkworms have been studied intensively since and sericin, the glue protein of silk, has been identified subsequently as the immunogenic agent (Panilaitis et al. 2003). The use of sericin-depleted fibroin scaffolds clearly increased the biocompatibility of silk matrices and Meinel et al could show that the biocompatibility of pure fibroin is comparable to collagen I and even superior to poly(d,l-lactic-co-glycolic acid) (PLGA) (Meinel et al. 2005). Thus, silk fibroin derived from silkworms has been used extensively as sponge-like scaffold for tissue engineering in vitro (Mandal \& Kundu 2009) and in vivo (MacIntosh et al. 2008, Unger et al.). But as a drawback, the high stability and tensile strength of silk fibroin comes along with low elasticity and hydrophilicity that lead to poor cell attachment in vitro. In addition, the low elasticity limits the use of silk fibroin scaffolds for TE of skeletal muscle.

Biodegradable synthetic polymers have also been widely used for muscle TE. Their advantages lie in easy handling and very good stability in vitro and in vivo. For example poly(l-lactic acid) (PLLA) and the more lipophilic co-polymer PLGA have been used in different orthopaedic applications due to their non-toxic properties and long-term stability in vivo (PLLA: 24 months, PLGA: approx. 6 months) (Gunatillake \& Adhikari 2003). Though, inflammatory responses (Bostman 1992) and cell toxic effects in vitro (Ignatius \& Claes 1996) have been reported due to the acidic degradation products of PLLA and PGA. One of the most frequently used synthetic polymer in TE research is poly( $\varepsilon$-caprolactone) (PCL). This biodegradable synthetic polymer shows a slow degradation rate resulting in a long-term stability of approximately 1 year in vivo (Bolgen et al. 2005). Furthermore, PCL is highly biocompatible and therefore suitable for in vivo applications (Cao et al. 2009). PCL has been used as films (Sarkar et al. 2008) and more frequently as electrospun fibers. However, PCL is also highly hydrophobic and therefore shows poor cell attachment in vitro (Zhang, $\mathrm{H}$. \& Hollister 2009). Hence, the hydrophobicity of PCL has to be attenuated before cell seeding through plasma treatment (Martins et al. 2009) or by coating the scaffold or blending with other materials like collagen to enhance cell attachment (Schnell et al. 2007, Zhang, Y.Z. et al. 2005). Among the variety of biodegradable synthetic polymers materials like poly(aniline) 
(PANi) (Borriello et al.) and oxidized polypyrrole (Gomez \& Schmidt 2007) stand out due to their electrical conductivity. Though their mechanical properties are similar to PCL including poor cell attachment, electrical conductivity is an interesting feature that qualifies those materials for muscle TE, especially ( $\mathrm{Li}$ et al. 2006).

Taking the properties of the most frequently used biopolymers and synthetic polymers into account, the complexity of mature skeletal muscle tissue asks for a combination of different complementary materials to engineer a matrix that meets the special demands of skeletal muscle TE. Composite scaffolds containing both, synthetic polymers for stability as well as biopolymers for enhanced cell attachment and elasticity, are therefore preferred in muscle TE research. E.g. PCL has been combined with collagen (Choi et al. 2008), gelatine (Kim, M.S. et al.), PLLA (Engelhardt et al.) and other materials. Also the combination of silk fibroin with collagen leads to suitable mechanical properties with good cell attachment in vitro (Wang, G. et al., Zhou et al.).

\subsection{Matrices}

Comparable to the wide variety of materials, the methods of processing different forms of matrices are equally numerous. Thereby, mechanical properties of a certain matrix, degradation rates and cell attachment depend on the scaffold's architecture. Whereas singlecell-layers can be easily cultured on two-dimensional scaffolds (films, micropatterned scaffolds), the architecture of three-dimensional scaffolds is more complex. To ensure cell survival and proliferation in vitro, a three-dimensional matrix should enable diffusion of oxygen, nutrients and metabolites as well as the migration of cells inside the scaffold. Otherwise, cells will only proliferate at the periphery but not in the scaffold's centre (IshaugRiley et al. 1998). Therefore, the most important features of matrices for three-dimensional TE are high porosity (ideally approximately $90 \%$ (Freed et al. 1994)), adequate pore-size (Lee et al have shown that a range of $50-200 \mu \mathrm{m}$ pore-size are sufficient for smooth muscle cells (Lee et al. 2008)) and high interconnectivity of the pores (van Tienen et al. 2002) to enable cell migration inside the matrix.

Concerning the pore size, hydrogels usually show freely diffusion of nutrients and oxygen. Cells incorporated in hydrogels can migrate through the scaffold by degrading the gel but at the same time the stability of the gel decreases continuously. Furthermore, the architecture of hydrogels randomly spread pores (Fig. 2). However, the natural extracellular matrix within functional skeletal muscle tissue is highly orientated.

The parallel alignment of ECM and skeletal muscle tissue is the pre-requisite for effective muscle contraction and force-generation along a longitudinal axis. Curtis and Wilkinson first described the "cell guidance theory" by demonstrating that microgrooved matrices with a parallel micropattern provoke parallel aligned cell growth along the pattern of the scaffold (Curtis \& Wilkinson 1997). This phenomenon is also present in myoblast culture (Choi et al. 2008, Huang et al. 2006, Huber et al. 2007) facilitating the generation of aligned myotubes (Gingras et al. 2009). Therefore, several techniques for aligned scaffold architecture have been developed including selective laser sintering or three-dimensional printing reviewed by Karande et al (Karande et al. 2004). Another method to gain spatially orientated pores in sponge-like matrices is unidirectional freeze-drying of materials like collagen (Madaghiele et al. 2008) or silk fibroin (Mandal \& Kundu 2009, 2009). Hydrogels are gradually frozen leading to controlled formation of ice crystals which result in controlled porosity after evaporation of the aqueous part of the hydrogel. Additionally, Schoof and coworkers demonstrated that also the pore-size can be controlled by variation of the freezing- 
temperature (Schoof et al. 2001). Though, there are certain disadvantages linked to the freeze-drying method. First of all, secondary surface modifications of the sponges like coating procedures to enhance cell attachment are difficult and sparsely controllable. Secondly, the alignment of the pores is only spatial whereas the architecture of the matrix surrounding the pores usually remains at random.

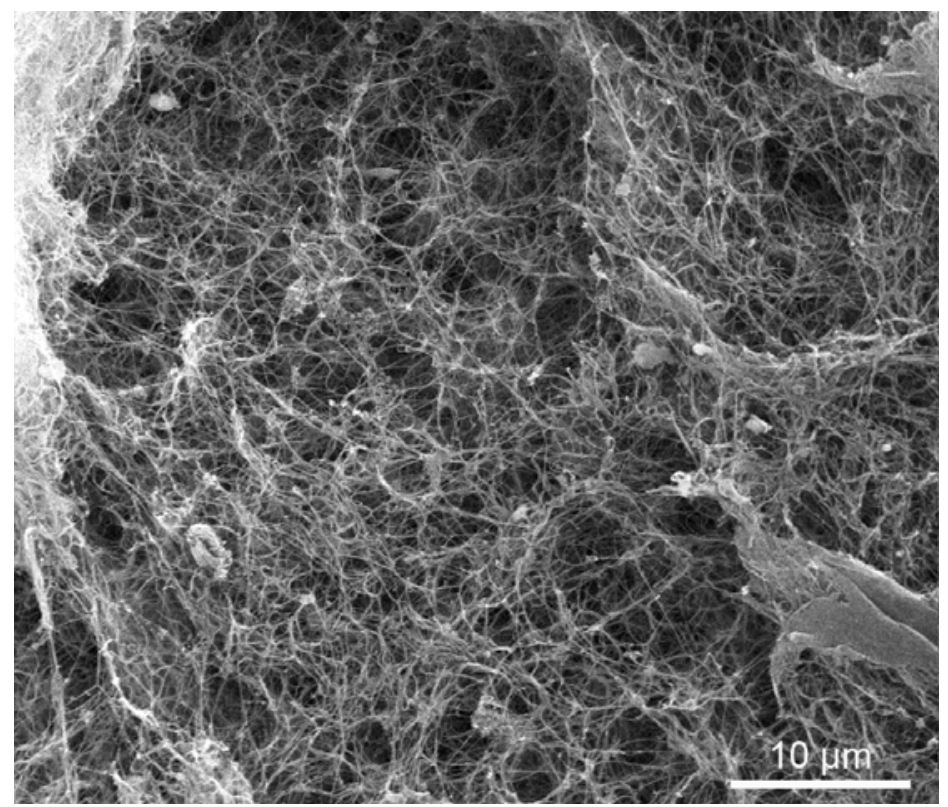

Fig. 2. Scanning Electron Microscopy (SEM) of a fibrin-collagen blend hydrogel. The aqueous part of the hydrogel is evaporated after critical point drying and fibrillar structures of fibrin and collagen is left behind. The random architecture of the hydrogel is clearly visible. 5000x magnification

On the contrary, electrospinning as an alternative method offers strict alignment of the resulting scaffolds (Ayres et al. 2006). The technique of electrospinning results in fibers formed by electrical voltage (Boudriot et al. 2006). Though, the process depends on multiple parameters, e.g. concentration and viscosity of the spinning solution, the voltage applied during the spinning process or flow rate of the spinning solution. The mechanical and chemical properties of electrospun matrices can be adjusted to the demands of the respective tissue by varying these parameters. Thus, a variety of synthetic and biopolymers can be electrospun at the micro- or nanoscale (Sell et al. 2009). Nanofibrous matrices electrospun from ECM proteins such as collagen I or hyaluronic acid mimic the natural ECM exactly and therefore ensure excellent cell attachment, cell viability and differentiation (Barnes et al. 2007). As mentioned before, biopolymers often lack the suitable stability for in vivo application, whereas the hydrophibicity of synthetic materials prevents rapid cell attachment. Again, the special demands of skeletal muscle TE can be met by combination of synthetic polymers and biopolymers. Different polymers can therefore be combined primarily by spinning polymer-blend solutions, core-shell spinning or co-spinning of different polymer solutions. Methods for secondary surface modification are coating 
(Riboldi et al. 2005) or plasma treatment (Martins et al. 2009) of the matrix after the spinning procedure. Blending different polymers, e.g. PCL and collagen (Fig. 3), is a very simple method to generate composite matrices that combine the properties of both polymers depending on the ratio (Schnell et al. 2007).

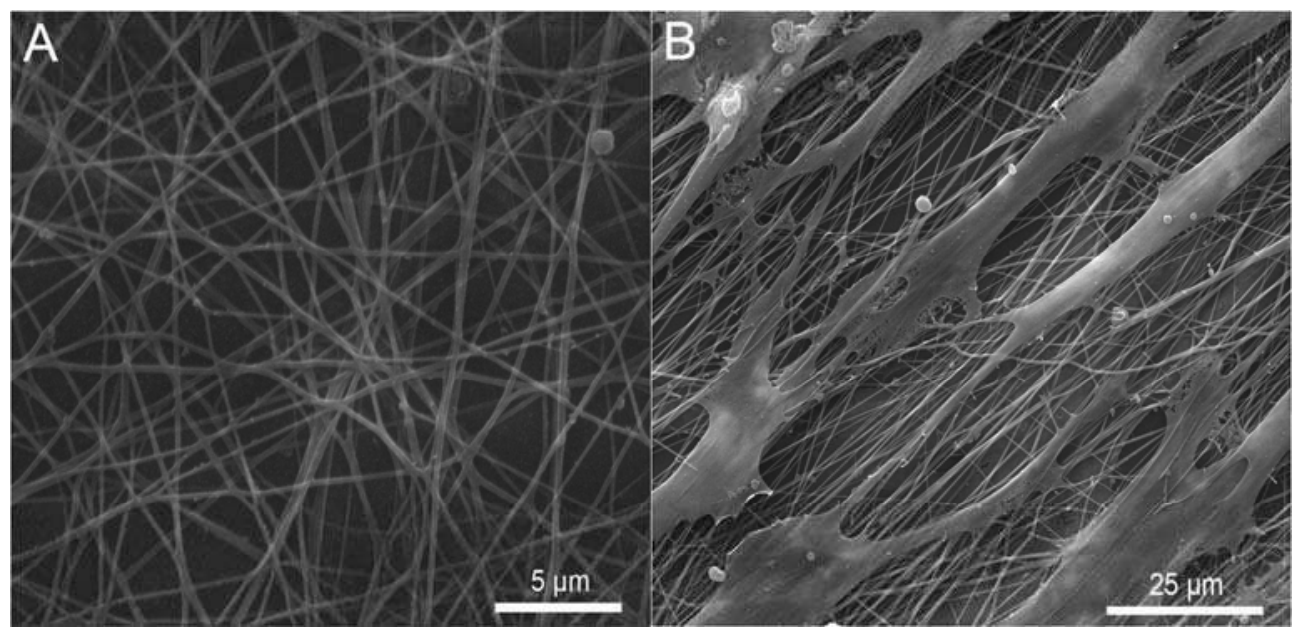

Fig. 3. Scanning Electron Microscopy (SEM) of electrospun PCL-collagen blend nanofibers. A: Randomly spun nanofibers. Magnification 10000x. B: Muscle precursor cells cultured on electrospun nanofibers with parallel alignment. The cell growth along the fibers' direction is clearly visible. Magnification 2500x

The more complex core-shell-spinning technique uses two separate polymers which are electrospun co-axially with the second polymer surrounding the first polymer at the core. Zhang et al used PCL as core fiber with a shell of collagen. They proved the core-shellnanofibers to be superior to collagen-coated PCL fibers regarding cell attachment in vitro (Zhang, Y.Z. et al. 2005). Jiang and co-workers have introduced electrospun core-shell fibers as drug delivery system (DDS) (Jiang et al. 2005). Thereafter, the emerging field of nanofibers and nanoparticles as DDS has found its way into TE research (Sill \& von Recum 2008). Controlled release of different drugs e.g. growth factors (Sahoo et al.) or angiogenic factors (Yang et al.) upgrades nanofiber matrices into "smart" matrices (Moroni et al. 2008). However, electrospinning of aligned nanofibrous matrices is linked with poor control of the pore size as the main disadvantage. The generation of electrospun three-dimensional matrices, especially, results in densely packed scaffolds (fig. 3) that hinder cell infiltration (Baker \& Mauck 2007, Telemeco et al. 2005). Therefore, co-spinning of water-soluble sacrificial fibers such as poly-(ethylene-oxide) (PEO) has been shown to overcome this problem (Baker et al. 2008). The sacrificial PEO fibers are interspersed inside the threedimensional matrix and dissolve easily in water and alcohol during sterilization procedure before cell seeding. The resulting interspaces between the residual fibers then enable cells to migrate through the matrix (Baker et al. 2008). Though the control of pore size and interspaces in orientated nanofiber matrices is still challenging, the electrospinning technique holds great potential for TE and regenerative medicine and therefore pretends to be the most promising matrix for skeletal muscle TE at the moment. 


\section{Cell source}

\subsection{The satellite cell}

Satellite cells form the major source for muscle regeneration in vivo after injury (Snow 1977). First described by Mauro in 1961 by electron microscopy, the term "satellite cell" was initially used for resident cells beneath the basal lamina of mature skeletal muscle fibers (Mauro 1961). Meanwhile, the "genetical footprint" of this cell population is well-known and satellite cells are specifically identified by expression of the transcription factor Pairedbox 7 (Pax7) (Seale et al. 2000). Furthermore, satellite cells express MyoD (also known as Myf5; Fig. 4), M-cadherin, c-Met, syndecan-3 and 4 (Cornelison et al. 2001) and CD 34 (Beauchamp et al. 2000). In the past, it has been a point of discussion whether satellite cells are stem cells or myogenic progenitor cells (Zammit et al. 2006). Kuang et al proved that a small sub-population, i.e. $10 \%$ of satellite cells, shows stemness properties and repopulate the satellite cell niche in vivo (Kuang et al. 2007). These true stem cells are positive for Pax7 but negative for MyoD, whereas the majority of satellite cells are also positive for MyoD. The myogenic transcription factor MyoD marks the commitment of activated satellite cells to the myogenic line (Weintraub et al. 1991).

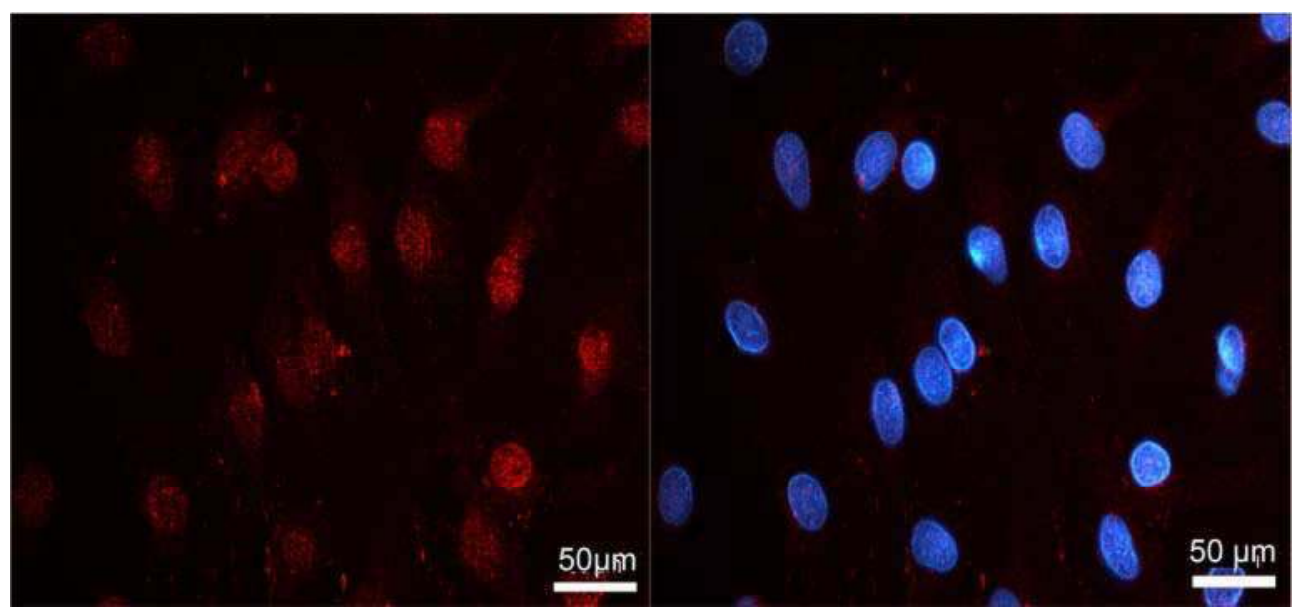

Fig. 4. Muscle precursor cells (MyoD positive cells) in vitro. Left side: Immnofluorescent staining for MyoD which is mainly located at the nuclei. Right side: Merge of MyoD staining and DAPI-counterstain. Magnification 400x

This myogenic imprinting renders the satellite cell to be a safe cell source for in vivo as well as clinical application without risking dedifferentiation and tumorigenesis. Therefore, satellite cells are the preferred cell source for clinically orientated muscle TE research (Otto et al. 2009). Kuang and his group have demonstrated that the $\mathrm{Pax} 7^{+} / \mathrm{MyoD}^{+}$cell population is renewed by the $\mathrm{Pax}^{+} / \mathrm{MyoD}^{-}$cells through asymmetric self-renewal (Kuang et al. 2007). MyoD-positive cells in turn regenerate injured muscle tissue by differentiation into new muscle fibers. Thus, even large muscle tissue defects can be regenerated by a relatively small cell population in vivo (Collins et al. 2005, Le Grand \& Rudnicki 2007). Unfortunately, this astonishing potential of self-renewal and myogenic differentiation of satellite cells in vivo is usually lost when satellite cells are isolated and cultured in vitro (Yaffe 1968). Boonen and 
his group proposed the loss of the satellite cell niche at the basal lamina in vivo (Boonen \& Post 2008). This highly specific niche preserves the stem cell status of quiescent satellite cells (Blau et al. 2001). Isolated satellite cells increase their expression of MyoD and differentiate after loosing contact with the basal lamina and thus loose their proliferative potential. Therefore, the generation of suitable numbers of satellite cells for muscle TE by in vitro culture and expansion is still challenging. Recently, Gilbert et al have demonstrated that the satellite cell function depends on substrate elasticity (Gilbert et al.). The group found the best proliferative potential of isolated satellite cells when cultured on PEG hydrogels crosslinked with laminin with an elasticity of $12 \mathrm{kPa}$ which equals the elasticity of muscle tissue in vivo. After implantation of the cultured cells in a muscle injury model in vivo the engraftment rate was even comparable to freshly isolated and directly implanted satellite cells. Hence, Gilbert and co-workers showed that the satellite cell niche can be mimicked in vitro and thus the proliferative potential of cultured satellite cells can be preserved.

Recently, the existence of yet another cell population in adult skeletal muscle tissue has been proved: The telocyte was described by Popescu et al in cardiac muscle tissue first (Popescu \& Faussone-Pellegrini). The typical shape of telocytes with their prolongations ("telopodes") situated in the vicinity of nerves, vessels and cardiomyocyte progenitors suggests a role in intercellular signalling as regulators in myocardial regeneration and as "nursing cells" for cardiac progenitors (Gherghiceanu \& Popescu). In a recent study, Popescu and his group have identified telocytes also in skeletal muscle tissue (Popescu 2011). Beside their typical prolongations, telocytes are known to express c-kit and caveolin-1, but are Pax7 negative and thus differ from the satellite cell population. Additionally, telocytes secrete VEGF (Suciu et al.).

\subsection{Stem cells}

Stem cells of different origin offer a unique proliferation potential as the main advantage. To date, adult stem cells play the most important role in TE research, though other sources exist (embryonic or induced pluripotent stem cells (iPSC) e.g.) (Klumpp et al.). Since engineering of three-dimensional tissue of skeletal muscle asks for a large quantity of muscle cells, adult stem cells are a suitable cell source in TE research and regenerative medicine (Barile et al. 2009, Mollmann et al. 2009, Roche et al. 2009). Therefore, mesenchymal stromal cells (MSC) are a feasible alternative cell source for skeletal muscle TE due to their high proliferation rates in vitro and their low imunogenicity in vivo (Chen, L. et al. 2009) that even enables allogenic transplantation of MSCs (García-Castro J 2008, Rossignol et al. 2009). MSCs can be derived from different tissues, e.g. from bone marrow (BMSC) or adipose tissue derived (ADSC) (Deans \& Elisseeff 2009). BMSCs are well-known and have been widely used for cytotherapy in regenerative medicine (Brazelton et al. 2003). However, in case of skeletal muscle TE, ADSCs should be preferred due to higher potential for myogenic differentiation as well as higher proliferation rate compared to BMSCs (Kern et al. 2006, Zhu et al. 2008). Still, the experiences of in vivo studies revealed a poor incorporation rate of transplanted MSCs into myofibers (Gussoni et al. 1997), ranging between 5 and 10\% of the transplanted MSCs in DMD patients (Brazelton et al. 2003, Gussoni et al. 1997). Low incorporation rates are the main obstacle for cytotherapie in clinical settings. Though, Satija and co-workers proposed paracrine effects of transplanted MSCs in vivo as an important therapeutic effect (Satija et al. 2009). Therefore, transplanted MSCs secrete different cytokines resulting in anti-inflammatory, angiogenic and anti-apoptotic effects (Meirelles Lda \& Nardi 2009, Sze et al. 2007) and thus facilitate local endogenous tissue repair (Nesselmann et al. 2008). Estrada and his group 
explained the angiogenic effect of MSC through their secretion of Cyr61 (Estrada et al. 2009) a key factor for angiogensis and tissue repair in vivo (Mo et al. 2002). Estrada et al demonstrated that the sole addition of MSC secretome stimulates angiogenesis in vitro and in vivo.

Though their poor incorporation into myofibers and - compared to satellite cells - less effective myogenic differentiation in vivo, the paracrine effects of MSCs could augment the cell viability and myogenic differentiation of co-transplanted satellite cells.

\section{Cell survival in vivo / vascularization}

Whereas the generation of two-dimensional skeletal muscle tissue in vitro has been demonstrated by several groups before (Dennis et al. 2001, Strohman et al. 1990), engineering three-dimensional muscle tissue exceeding the size of $1 \mathrm{~mm}$ in vitro is still a challenge. Since common in vitro cultures of muscle precursor cells depend on diffusion solely, the thickness of generated tissue is limited to $500 \mu \mathrm{m}$ to prevent apoptosis of cells in the central region of the construct (Kannan et al. 2005). Herein, Freed and co-workers proved the superiority of dynamic flow culturing due to enhanced diffusion capacity compared to static culture conditions (Freed et al. 1994). Still, the in vitro generation of relevant tissue sizes asks for an adequate vascularization. Levenberg and his group proved that vascularization of skeletal or cardiac muscle in vitro is possible and enhances the transport of nutrients and metabolites (Lesman et al. 2010, Levenberg et al. 2005). In their study they co-cultured muscle precursor cells with embryonic fibroblasts and endothelial cells seeded into a 3D polymer scaffold. When implanted in vivo, the in vitro generated vessels connected to vessels of the host and the tissue showed less apoptosis (Levenberg et al. 2005). However, even this approach does not meet the demands of a clinical setting, since the muscle tissue, engineered in vitro, requires an axial vascularization to enable the transplantation in vivo including a microsurgical anastomosis to the recipient site. In most in vivo experiments, matrices and muscle precursor cells are implanted subcutaneously leading to random vessel ingrowth from the constructs' periphery. In contrast to subcutaneous in vivo models, O. O. Erol and M. Spira introduced the arterio-venous (AV) loop model of the rat in 1980 (Erol \& Sira 1980). For this in vivo model an AV-loop is created microsurgically between the saphenous artery and vein (Fig. 5) which can be implanted into various matrices (Polykandriotis et al. 2008).

Thus, vascularization in general as well as number and pattern of vessel ingrowth of different matrices can be analyzed (Arkudas et al. 2010, Polykandriotis et al. 2009) and the vascularized matrix offers a platform for tissue engineering for skeletal (Messina et al. 2005) or cardiac (Morritt et al. 2007) muscle in vivo. The feasibility of the AV-loop model in large animals (Beier et al. 2009) has been demonstrated recently and poses another step towards a more clinical setting (Beier et al. 2010).

Depending on the matrix architecture, a certain period of time is necessary for vascularization of the whole construct. This pre-vascularization time plays an important role for survival rates of implanted cells in vivo: Thus, cells implanted after this time period show significantly lower apoptosis rates (Arkudas et al. 2007). Vascular growth factors such as bFGF and VEGF (Yancopoulos et al. 2000) are frequently used to reduce the prevascularization time in vivo (Arkudas et al. 2007). Therefore, different approaches have been tried for controlled drug release of VEGF. Beside the use as soluble factor or immobilized in fibrin hydrogels (Arkudas et al. 2007), VEGF can be bound to nanoparticles (des Rieux et al.) or nanofibers (Vournakis et al. 2008) as drug delivery systems (DDS) to improve angiogenesis in vivo (Zisch et al. 2003). Kim et al have demonstrated the positive therapeutic 
effect of nanoparticle based VEGF release in ischemic muscle tissue (Kim, J. et al.). Hypoxiaregulated systems enable an even more selective delivery of VEGF to ischemic sites only, e.g. in myocardial repair (Ye et al.). Finally, the VEGF expression of (co-) implanted MSCs could also enhance angiogenesis in vivo.

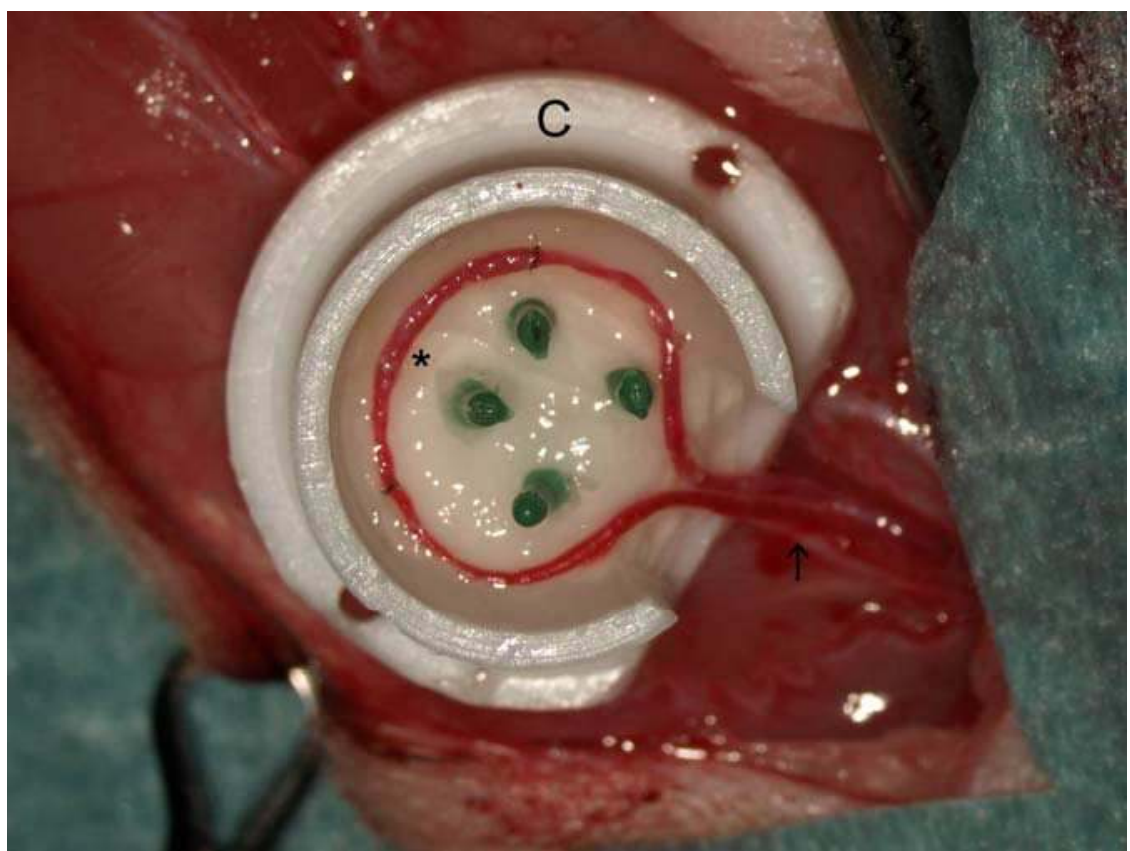

Fig. 5. Arterio-venous loop model in the rat as previously published by our group. The AVloop (asterisk) is implanted into a Teflon chamber (C) filled with fibrin hydrogel. In this setting, the engineered tissue could be transplanted by anastomosing the pedicle (arrow) to the recipient site

Beside angiogenic growth factors, other factors such as insulin-like growth factor-1 (IGF-1) have been shown to increase survival rates of implanted cells in vivo (Wang, F. et al. 2009) and to improve myocardial regeneration (Davis et al. 2006, Padin-Iruegas et al. 2009). Thus, various methods exist to further ameliorate cell survival in vivo but still have to be analyzed in detail for their benefit for skeletal muscle TE.

\section{Myogenic differentiation}

\subsection{Molecular factors for myogenic differentiation}

Beside the improvement of cell survival rates, the myogenic differentiation of implanted muscle precursor cells into functional skeletal muscle tissue in vivo is another point that has to be addressed by future research. To date, many different molecular factors have been identified which support myogenic differentiation, e.g. akirin-1, muscle specific microRNAs and insulin-like growth factor (IGF-1).

The well-known factor IGF-1 has been demonstrated to increase the proliferation as well as myogenic differentiation of myoblasts in vitro by Allen and Boxhorn (Allen \& Boxhorn 
1989). Later on, this effect was affirmed in different in vivo experiments with overexpression of IGF-1 leading to muscle hypertrophy (Adams \& McCue 1998) and improving muscle regeneration after trauma (Menetrey et al. 2000, Sato et al. 2003). Whereas many growth factors increase proliferation rates or differentiation of myoblasts only, IGF-1 enhances both, proliferation as well as myogenic differentiation of muscle precursor cells (Ten Broek et al.). Furthermore, IGF-1 overexpression improves survival rates of implanted cells in vivo (Wang, F. et al. 2009). These properties render IGF-1 as one of the most potential growth factors for myogenesis and skeletal muscle TE. Beside the mitogenic potential of IFG-1 and its positive influence on myogenesis, Haider et al have also shown that IGF-1 can mobilize stem cells and increase engraftment of implanted MSCs in vivo (Haider et al. 2008). The group explained this effect of IGF-1 through its activation of stromal cell derived factor (SDF)-1a and its receptor CXCR4. SDF-1a plays a crucial role in skeletal muscle regeneration and is therefore overexpressed after muscle injury as well as in dystrophic muscle to attract muscle precursor cells which express CXCR4 (Perez et al. 2009). Therefore, overexpression of SDF1a through transfected MSCs (Haider et al. 2008) or via controlled drug release (Grefte et al.) improves regeneration of skeletal as well as cardiac muscle in vivo.

Another factor which influences early myogenic differentiation positively is akirin-1 (also known as Mighty) (Salerno et al. 2009). In skeletal muscle tissue, akirin-1 is known to activate quiescent satellite cells and thus promote proliferation of muscle precursor cells. Furthermore, akirin-1 consecutively induces the expression of IGF-2 and hence also increases myogenic differentiation indirectly (Marshall et al. 2008). Therefore, akirin-1 combines the activation of quiescent satellite cells with the promyogenic effect of downstream growth factors such as IGFs. Though promising for skeletal muscle TE, the mechanism and molecular pathways of akirin-1 still have to be analysed in detail in future. In addition, the administration of growth factors has to be critically analyzed concerning their risk of tumorigenicity in vivo.

Recently, a novel class of regulating factors of myogenesis has been analyzed for their promyogenic potential: Small non-coding RNAs, called microRNA (miRNA) which consist of approximately 20-22 nucleotides (Callis et al. 2008). Herein, certain microRNAs (miR-1, miR-133 and miR-206) have been demonstrated as muscle specific. Whereas miR-1 and miR133 are also expressed in cardiac muscle, miR-206 is specifically expressed in skeletal muscle tissue and up-regulated in patients with muscular dystrophy (Eisenberg et al. 2009). Furthermore, the muscle-specific miRNAs differ in their effect on muscle precursor cells. MiR-133 increases proliferation of muscle precursor cells but also inhibits myogenic differentiation (Chen, J.F. et al. 2006). On the contrary, miR-1 and miR-206 have been shown to induce myogenic differentiation (Chen, J.F. et al. 2006, Kim, H.K. et al. 2006). In a recent study, Nakasa et al demonstrated that local injection of miR-1, miR-133 and miR-206 improves muscle regeneration and prevent fibrosis following muscle injury in vivo (Nakasa et al.). However, further studies are still necessary to analyze the promyogenic potential of muscle-specific microRNAs in vitro and in vivo.

\subsection{Electrical stimulation and neurotization}

Despite great efforts in the past and various molecular factors which regulate and enhance myogenesis, engineering of mature skeletal muscle tissue still remains a big challenge. Though contracting myotubes - which mark the differentiation and fusion of myoblasts in myogenesis - have been generated by various groups, the generation of adult muscle fibers depends on neural or electrical stimulation (Wilson \& Harris 1993). The influence of electrical stimulation on further myogenic differentiation has been analyzed in vitro 
(Donnelly et al., Stern-Straeter et al. 2005) and in vivo (Fujita et al. 2007). For clinical applications, devices for electrical stimulation have to be implantable and suitable for longterm stimulation (Jarvis \& Salmons 2001, Lanmuller et al. 2005). The in vivo experiments of Dennis and co-workers using implantable stimulation devices in the rat demonstrated that muscle mass as well as the maximum force of a denervated muscle can be maintained by electrical stimulation (Dennis et al. 2003). Thus, the physiologic stimulation via motoric innervation can be simulated to support further myogenic differentiation.

Liao et al showed that the combination of electrical stimulation with aligned micropatterned matrices even increases the positive effect on myogenic differentiation (Liao et al. 2008). Again, electrospun nanofibrous matrices offer the possibility to combine cell guidance through aligned matrix architecture with electrical stimulation via conductive nanofibers. Ghasemi-Mobarakeh and colleagues used electrospun PANi/PCL/gelatine-blend fibers as matrix for neural cell cultivation. Applying electrical stimulation to the matrices, they demonstrated enhanced cell proliferation and neurite outgrowth (Ghasemi-Mobarakeh et al. 2009). The use of PANi/gelatine-blend fibers offers an acceptable cell attachment in vitro and can be used for cultivation and electrical stimulation of muscle cells in vitro (Li et al. 2006). Finally, the influence of electrical stimulation on $\mathrm{C} 2 \mathrm{C} 12$ murine myoblasts was analyzed by Jun and his group in vitro. In their experiments they found that electrical stimulation enhances myogenic differentiation via upregulation of myogenin which specifically marks early myogenesis (Jun et al. 2009).

However, engineering functional skeletal muscle tissue in vivo not only asks for highly differentiated and organised muscle fibers but also the formation of neuromuscular junctions and neurite ingrowth between the muscle fibers is necessary (Fig. 6).

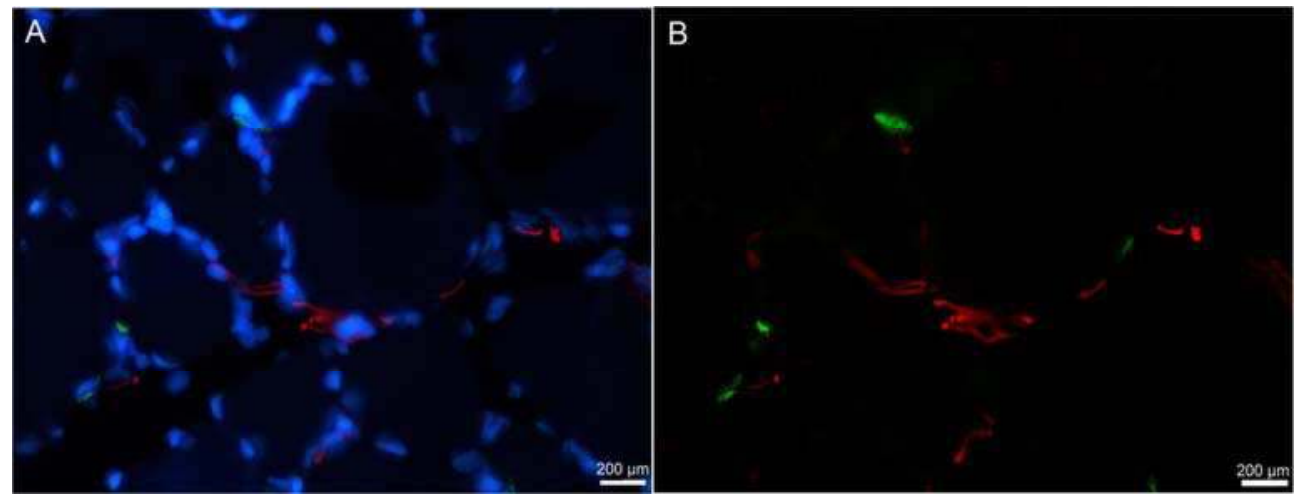

Fig. 6. Immunofluorescent staining of a cross-section of adult skeletal muscle. A: The nuclei are stained with DAPI (blue) and mark the outline of the muscle fibers. The acetylcholine receptors (specifically stained with a-bungarotoxin; green) are reached by nerve terminals (stained for specific neurofilament (NF-100), red) forming the neuromuscular junction (B: DAPI-filter excluded). Magnification 400x

The main component of the neuromuscular junction - the acetylcholine receptor (AChR) - is initially expressed in developing myofibers also in absence of neural cells, i.e. independent from motoric innervation (Witzemann 2006). The AChR clusters at this stage of myogenesis are located at the central regions of myofibers and this phenomenon known as "prepatterning", marks the development of mature myofibers in myogenesis. However, the 
accumulation of AChR at synaptic sites and further development into functional neuromuscular junctions depends on the specific neuronal factor agrin. Thus, the molecular signalling between developing myofibers and motor neurons is necessary for the generation of functional neuromuscular junctions (Brockhausen et al. 2008). The motoric innervation even defines further maturation of the developing muscle tissue into slow- or fast-twitching muscle fibers (Nehrer-Tairych et al. 2000). Dhawan et al proved that motoric neurotization of implanted muscle precursor cells in vivo leads to the formation of neuromuscular junctions (Dhawan et al. 2007). In a comprehensive study, they showed nerve-induced contractions of the in vivo engineered skeletal muscle tissue after explantation and analysis in vitro. Therefore, a successful approach for skeletal muscle TE in vivo will necessarily include a motor nerve for neurotization of implanted muscle precursor cells. But to date, in vivo models combining motoric neurotization with a pre-vascularized matrix are still rare. Recently, a new AV-loop model in the rat including motoric neurotization has been developed by our group (unpublished data).

\section{Conclusions}

As a conclusion, the main challenges in skeletal muscle TE are therefore: (1) engineering a suitable matrix for muscle TE including a clinical application, (2) improving further myogenic differentiation in vivo and (3) enabling the transplantation of functional skeletal muscle tissue to the recipient site including microsurgical anastomosis of an adequate vasculature as well as motoric neurotization of the engineered muscle tissue. Despite these obstacles, the achievements of the recent years demonstrate an encouraging progress of skeletal muscle TE research. Therefore, Churchill's statement concerning skeletal muscle TE in vitro may still come true in the future.

\section{References}

Adams, G. R. \& McCue, S. A., (1998), Localized infusion of IGF-I results in skeletal muscle hypertrophy in rats. J Appl Physiol, 84. 5, p. 1716-22.

Allen, R. E. \& Boxhorn, L. K., (1989), Regulation of skeletal muscle satellite cell proliferation and differentiation by transforming growth factor-beta, insulin-like growth factor I, and fibroblast growth factor. J Cell Physiol, 138. 2, p. 311-5.

Arkudas, A. et al., (2007), Axial prevascularization of porous matrices using an arteriovenous loop promotes survival and differentiation of transplanted autologous osteoblasts. Tissue Eng, 13. 7, p. 1549-60.

Arkudas, A. et al., (2010), Automatic Quantitative Micro-Computed Tomography Evaluation of Angiogenesis in an Axially Vascularized Tissue-Engineered Bone Construct. Tissue Eng Part C Methods, .

Arkudas, A. et al., (2009), Dose-finding study of fibrin gel-immobilized vascular endothelial growth factor 165 and basic fibroblast growth factor in the arteriovenous loop rat model. Tissue Eng Part A, 15. 9, p. 2501-11.

Arkudas, A. et al., (2007), Fibrin gel-immobilized VEGF and bFGF efficiently stimulate angiogenesis in the AV loop model. Mol Med, 13. 9-10, p. 480-7.

Ayres, C. et al., (2006), Modulation of anisotropy in electrospun tissue-engineering scaffolds: Analysis of fiber alignment by the fast Fourier transform. Biomaterials, 27. 32, p. 5524-34. 
Baker, B. M. et al., (2008), The potential to improve cell infiltration in composite fiberaligned electrospun scaffolds by the selective removal of sacrificial fibers. Biomaterials, 29. 15, p. 2348-58.

Baker, B. M. \& Mauck, R. L., (2007), The effect of nanofiber alignment on the maturation of engineered meniscus constructs. Biomaterials, 28. 11, p. 1967-77.

Barile, L. et al., (2009), Bone marrow-derived cells can acquire cardiac stem cells properties in damaged heart. J Cell Mol Med, .

Barnes, C. P. et al., (2007), Nanofiber technology: designing the next generation of tissue engineering scaffolds. Adv Drug Deliv Rev, 59. 14, p. 1413-33.

Beauchamp, J. R. et al., (2000), Expression of CD34 and Myf5 defines the majority of quiescent adult skeletal muscle satellite cells. J Cell Biol, 151. 6, p. 1221-34.

Beier, J. P. et al., (2009), De novo generation of axially vascularized tissue in a large animal model. Microsurgery, 29. 1, p. 42-51.

Beier, J. P. et al., (2010), Axial vascularization of a large volume calcium phosphate ceramic bone substitute in the sheep AV loop model. J Tissue Eng Regen Med, 4. 3, p. 216-23.

Beier, J. P. et al., (2009), Collagen matrices from sponge to nano: new perspectives for tissue engineering of skeletal muscle. BMC Biotechnol, 9. p. 34.

Blau, H. M., Brazelton, T. R. \& Weimann, J. M., (2001), The evolving concept of a stem cell: entity or function? Cell, 105. 7, p. 829-41.

Bolgen, N. et al., (2005), In vitro and in vivo degradation of non-woven materials made of poly(epsilon-caprolactone) nanofibers prepared by electrospinning under different conditions. J Biomater Sci Polym Ed, 16. 12, p. 1537-55.

Boonen, K. J. \& Post, M. J., (2008), The muscle stem cell niche: regulation of satellite cells during regeneration. Tissue Eng Part B Rev, 14. 4, p. 419-31.

Borriello, A. et al., Optimizing PANi doped electroactive substrates as patches for the regeneration of cardiac muscle. J Mater Sci Mater Med, .

Bostman, O. M., (1992), Intense granulomatous inflammatory lesions associated with absorbable internal fixation devices made of polyglycolide in ankle fractures. Clin Orthop Relat Res, 278, p. 193-9.

Boudriot, U. et al., (2006), Electrospinning approaches toward scaffold engineering--a brief overview. Artif Organs, 30. 10, p. 785-92.

Brazelton, T. R., Nystrom, M. \& Blau, H. M., (2003), Significant differences among skeletal muscles in the incorporation of bone marrow-derived cells. Dev Biol, 262. 1, p. 64-74.

Brockhausen, J. et al., (2008), Neural agrin increases postsynaptic ACh receptor packing by elevating rapsyn protein at the mouse neuromuscular synapse. Dev Neurobiol, 68. 9, p. 1153-69.

Callis, T. E. et al., (2008), Muscling through the microRNA world. Exp Biol Med (Maywood), 233. 2, p. 131-8.

Cao, H. et al., (2009), The topographical effect of electrospun nanofibrous scaffolds on the in vivo and in vitro foreign body reaction. J Biomed Mater Res $A$, .

Chen, J. F. et al., (2006), The role of microRNA-1 and microRNA-133 in skeletal muscle proliferation and differentiation. Nat Genet, 38. 2, p. 228-33.

Chen, L. et al., (2009), Analysis of allogenicity of mesenchymal stem cells in engraftment and wound healing in mice. PLoS One, 4. 9, p. e7119.

Choi, J. S. et al., (2008), The influence of electrospun aligned poly(epsiloncaprolactone)/collagen nanofiber meshes on the formation of self-aligned skeletal muscle myotubes. Biomaterials, 29. 19, p. 2899-906. 
Churchill, W. S., (1932), Thoughts and Adventures First English Edition .

Collins, C. A. et al., (2005), Stem cell function, self-renewal, and behavioral heterogeneity of cells from the adult muscle satellite cell niche. Cell, 122. 2, p. 289-301.

Cornelison, D. D. et al., (2001), Syndecan-3 and syndecan-4 specifically mark skeletal muscle satellite cells and are implicated in satellite cell maintenance and muscle regeneration. Dev Biol, 239. 1, p. 79-94.

Curtis, A. \& Wilkinson, C., (1997), Topographical control of cells. Biomaterials, 18. 24, p. 1573-83.

Davis, M. E. et al., (2006), Local myocardial insulin-like growth factor 1 (IGF-1) delivery with biotinylated peptide nanofibers improves cell therapy for myocardial infarction. Proc Natl Acad Sci U S A, 103. 21, p. 8155-60.

Deans, T. L. \& Elisseeff, J. H., (2009), Stem cells in musculoskeletal engineered tissue. Curr Opin Biotechnol, 20. 5, p. 537-44.

Dennis, R. G., Dow, D. E. \& Faulkner, J. A., (2003), An implantable device for stimulation of denervated muscles in rats. Med Eng Phys, 25. 3, p. 239-53.

Dennis, R. G. et al., (2001), Excitability and contractility of skeletal muscle engineered from primary cultures and cell lines. Am J Physiol Cell Physiol, 280. 2, p. C288-95.

des Rieux, A. et al., 3D systems delivering VEGF to promote angiogenesis for tissue engineering. J Control Release, 150. 3, p. 272-8.

Dhawan, V. et al., (2007), Neurotization improves contractile forces of tissue-engineered skeletal muscle. Tissue Eng, 13. 11, p. 2813-21.

Donnelly, K. et al., A novel bioreactor for stimulating skeletal muscle in vitro. Tissue Eng Part C Methods, 16. 4, p. 711-8.

Eisenberg, I., Alexander, M. S. \& Kunkel, L. M., (2009), miRNAS in normal and diseased skeletal muscle. J Cell Mol Med, 13. 1, p. 2-11.

Engelhardt, E. M. et al., A collagen-poly(lactic acid-co-varepsilon-caprolactone) hybrid scaffold for bladder tissue regeneration. Biomaterials, 32. 16, p. 3969-76.

Erol, O. O. \& Sira, M., (1980), New capillary bed formation with a surgically constructed arteriovenous fistula. Plast Reconstr Surg, 66. 1, p. 109-15.

Estrada, R. et al., (2009), Secretome from mesenchymal stem cells induces angiogenesis via Cyr61. J Cell Physiol, 219. 3, p. 563-71.

Freed, L. E. et al., (1994), Kinetics of chondrocyte growth in cell-polymer implants. Biotechnol Bioeng, 43. 7, p. 597-604.

Freed, L. E. et al., (1994), Biodegradable polymer scaffolds for tissue engineering. Biotechnology (N Y), 12. 7, p. 689-93.

Fujita, H., Nedachi, T. \& Kanzaki, M., (2007), Accelerated de novo sarcomere assembly by electric pulse stimulation in C2C12 myotubes. Exp Cell Res, 313. 9, p. 1853-65.

García-Castro J, T. C., Madrenas J, Pérez-Simón JA, Rodriguez R, Menendez P., (2008), Mesenchymal stem cells and their use as cell replacement therapy and disease modelling tool. J Cell Mol Med. , 12. (6B), p. 2552-65.

Ghasemi-Mobarakeh, L. et al., (2009), Electrical stimulation of nerve cells using conductive nanofibrous scaffolds for nerve tissue engineering. Tissue Eng Part A, 15. 11, p. 3605-19.

Gherghiceanu, M. \& Popescu, L. M., Cardiomyocyte precursors and telocytes in epicardial stem cell niche: electron microscope images. J Cell Mol Med, 14. 4, p. 871-7.

Gilbert, P. M. et al., Substrate elasticity regulates skeletal muscle stem cell self-renewal in culture. Science, 329. 5995, p. 1078-81.

Gingras, J. et al., (2009), Controlling the orientation and synaptic differentiation of myotubes with micropatterned substrates. Biophys J, 97. 10, p. 2771-9. 
Gomez, N. \& Schmidt, C. E., (2007), Nerve growth factor-immobilized polypyrrole: bioactive electrically conducting polymer for enhanced neurite extension. J Biomed Mater Res A, 81. 1, p. 135-49.

Grefte, S. et al., Skeletal muscle fibrosis: the effect of stromal-derived factor-1\&\#x03B1;loaded collagen scaffolds. Regen Med, 5. 5, p. 737-47.

Gunatillake, P. A. \& Adhikari, R., (2003), Biodegradable synthetic polymers for tissue engineering. Eur Cell Mater, 5. p. 1-16; discussion 16.

Gussoni, E., Blau, H. M. \& Kunkel, L. M., (1997), The fate of individual myoblasts after transplantation into muscles of DMD patients. Nat Med, 3. 9, p. 970-7.

Haider, H. et al., (2008), IGF-1-overexpressing mesenchymal stem cells accelerate bone marrow stem cell mobilization via paracrine activation of SDF-1alpha/CXCR4 signaling to promote myocardial repair. Circ Res, 103. 11, p. 1300-8.

Huang, N. F. et al., (2006), Myotube assembly on nanofibrous and micropatterned polymers. Nano Lett, 6. 3, p. 537-42.

Huber, A., Pickett, A. \& Shakesheff, K. M., (2007), Reconstruction of spatially orientated myotubes in vitro using electrospun, parallel microfibre arrays. Eur Cell Mater, 14. p. 56-63.

Ignatius, A. A. \& Claes, L. E., (1996), In vitro biocompatibility of bioresorbable polymers: poly(L, DL-lactide) and poly(L-lactide-co-glycolide). Biomaterials, 17. 8, p. 831-9.

Ishaug-Riley, S. L. et al., (1998), Three-dimensional culture of rat calvarial osteoblasts in porous biodegradable polymers. Biomaterials, 19. 15, p. 1405-12.

Jarvis, J. C. \& Salmons, S., (2001), The application and technology of implantable neuromuscular stimulators: an introduction and overview. Med Eng Phys, 23. 1, p. 3-7.

Jiang, H. et al., (2005), A facile technique to prepare biodegradable coaxial electrospun nanofibers for controlled release of bioactive agents. J Control Release, 108. 2-3, p. 237-43.

Jun, I., Jeong, S. \& Shin, H., (2009), The stimulation of myoblast differentiation by electrically conductive sub-micron fibers. Biomaterials, 30. 11, p. 2038-47.

Kaji, H. et al., Electrically induced contraction of $\mathrm{C} 2 \mathrm{C} 12$ myotubes cultured on a porous membrane-based substrate with muscle tissue-like stiffness. Biomaterials, 31. 27, p. 6981-6.

Kannan, R. Y. et al., (2005), The roles of tissue engineering and vascularisation in the development of micro-vascular networks: a review. Biomaterials, 26. 14, p. 1857-75.

Karande, T. S., Ong, J. L. \& Agrawal, C. M., (2004), Diffusion in musculoskeletal tissue engineering scaffolds: design issues related to porosity, permeability, architecture, and nutrient mixing. Ann Biomed Eng, 32. 12, p. 1728-43.

Kern, S. et al., (2006), Comparative analysis of mesenchymal stem cells from bone marrow, umbilical cord blood, or adipose tissue. Stem Cells, 24. 5, p. 1294-301.

Kim, H. K. et al., (2006), Muscle-specific microRNA miR-206 promotes muscle differentiation. J Cell Biol, 174. 5, p. 677-87.

Kim, J. et al., Targeted delivery of nanoparticles to ischemic muscle for imaging and therapeutic angiogenesis. Nano Lett, 11. 2, p. 694-700.

Kim, J. et al., (2003), Muscle tissue engineering for partial glossectomy defects. Arch Facial Plast Surg, 5. 5, p. 403-7.

Kim, M. S. et al., The development of genipin-crosslinked poly(caprolactone) (PCL)/gelatin nanofibers for tissue engineering applications. Macromol Biosci, 10. 1, p. 91-100. 
Klumpp, D. et al., (2010), Skeletal Muscle Tissue Engineering - Current Concepts and Future Perspectives. Handchir Mikrochir Plast Chir, .

Klumpp, D. et al., Engineering Skeletal Muscle Tissue-New Perspectives in vitro and in vivo. J Cell Mol Med, .

Kroehne, V. et al., (2008), Use of a novel collagen matrix with oriented pore structure for muscle cell differentiation in cell culture and in grafts. J Cell Mol Med, .

Kuang, S. et al., (2007), Asymmetric self-renewal and commitment of satellite stem cells in muscle. Cell, 129. 5, p. 999-1010.

Kumar, P. A. \& Hassan, K. M., (2002), Cross-face nerve graft with free-muscle transfer for reanimation of the paralyzed face: a comparative study of the single-stage and twostage procedures. Plast Reconstr Surg, 109. 2, p. 451-62; discussion 463-4.

Lanmuller, H. et al., (2005), Implantable device for long-term electrical stimulation of denervated muscles in rabbits. Med Biol Eng Comput, 43. 4, p. 535-40.

Le Grand, F. \& Rudnicki, M. A., (2007), Skeletal muscle satellite cells and adult myogenesis. Curr Opin Cell Biol, 19. 6, p. 628-33.

Lee, M., Wu, B. M. \& Dunn, J. C., (2008), Effect of scaffold architecture and pore size on smooth muscle cell growth. J Biomed Mater Res A, 87. 4, p. 1010-6.

Lesman, A., Gepstein, L. \& Levenberg, S., (2010), Vascularization shaping the heart. Ann N Y Acad Sci, 1188. p. 46-51.

Levenberg, S. et al., (2005), Engineering vascularized skeletal muscle tissue. Nat Biotechnol, 23. 7, p. 879-84.

Li, M. et al., (2006), Electrospinning polyaniline-contained gelatin nanofibers for tissue engineering applications. Biomaterials, 27. 13, p. 2705-15.

Liao, I. C. et al., (2008), Effect of Electromechanical Stimulation on the Maturation of Myotubes on Aligned Electrospun Fibers. Cell Mol Bioeng, 1. 2-3, p. 133-145.

MacIntosh, A. C. et al., (2008), Skeletal tissue engineering using silk biomaterials. J Tissue Eng Regen Med, 2. 2-3, p. 71-80.

Madaghiele, M. et al., (2008), Collagen-based matrices with axially oriented pores. J Biomed Mater Res A, 85. 3, p. 757-67.

Mandal, B. B. \& Kundu, S. C., (2009), Cell proliferation and migration in silk fibroin 3D scaffolds. Biomaterials, 30. 15, p. 2956-65.

Mandal, B. B. \& Kundu, S. C., (2009), Osteogenic and adipogenic differentiation of rat bone marrow cells on non-mulberry and mulberry silk gland fibroin 3D scaffolds. Biomaterials, 30. 28, p. 5019-30.

Marshall, A. et al., (2008), Mighty is a novel promyogenic factor in skeletal myogenesis. Exp Cell Res, 314. 5, p. 1013-29.

Martins, A. et al., (2009), Surface modification of electrospun polycaprolactone nanofiber meshes by plasma treatment to enhance biological performance. Small, 5. 10, p. 1195206.

Mauro, A., (1961), Satellite cell of skeletal muscle fibers. J Biophys Biochem Cytol, 9. p. 493-5.

Meinel, L. et al., (2005), The inflammatory responses to silk films in vitro and in vivo. Biomaterials, 26. 2, p. 147-55.

Meinhart, J., Fussenegger, M. \& Hobling, W., (1999), Stabilization of fibrin-chondrocyte constructs for cartilage reconstruction. Ann Plast Surg, 42. 6, p. 673-8.

Meirelles Lda, S. \& Nardi, N. B., (2009), Methodology, biology and clinical applications of mesenchymal stem cells. Front Biosci, 14. p. 4281-98. 
Menetrey, J. et al., (2000), Growth factors improve muscle healing in vivo. J Bone Joint Surg Br, 82. 1, p. 131-7.

Messina, A. et al., (2005), Generation of a vascularized organoid using skeletal muscle as the inductive source. FASEB J, 19. 11, p. 1570-2.

Mo, F. E. et al., (2002), CYR61 (CCN1) is essential for placental development and vascular integrity. Mol Cell Biol, 22. 24, p. 8709-20.

Mollmann, H. et al., (2009), Stem cell-mediated natural tissue engineering. J Cell Mol Med, .

Moroni, L., de Wijn, J. R. \& van Blitterswijk, C. A., (2008), Integrating novel technologies to fabricate smart scaffolds. J Biomater Sci Polym Ed, 19. 5, p. 543-72.

Morritt, A. N. et al., (2007), Cardiac tissue engineering in an in vivo vascularized chamber. Circulation, 115. 3, p. 353-60.

Mosesson, M. W., (2005), Fibrinogen and fibrin structure and functions. J Thromb Haemost, 3. 8, p. 1894-904.

Nakasa, T. et al., Acceleration of muscle regeneration by local injection of muscle-specific microRNAs in rat skeletal muscle injury model. J Cell Mol Med, 14. 10, p. 2495-505.

Nehrer-Tairych, G. V. et al., (2000), The influence of the donor nerve on the function and morphology of a mimic muscle after cross innervation: an experimental study in rabbits. Br J Plast Surg, 53. 8, p. 669-75.

Nesselmann, C. et al., (2008), Mesenchymal stem cells and cardiac repair. J Cell Mol Med, 12. 5B, p. 1795-810.

Otto, A., Collins-Hooper, H. \& Patel, K., (2009), The origin, molecular regulation and therapeutic potential of myogenic stem cell populations. J Anat, 215. 5, p. 477-97.

Padin-Iruegas, M. E. et al., (2009), Cardiac progenitor cells and biotinylated insulin-like growth factor-1 nanofibers improve endogenous and exogenous myocardial regeneration after infarction. Circulation, 120. 10, p. 876-87.

Panilaitis, B. et al., (2003), Macrophage responses to silk. Biomaterials, 24. 18, p. 3079-85.

Peng, Y. Y. et al., (2010), Evaluation of the immunogenicity and cell compatibility of avian collagen for biomedical applications. J Biomed Mater Res A, 93. 4, p. 1235-44.

Perez, A. L. et al., (2009), CXCR4 enhances engraftment of muscle progenitor cells. Muscle Nerve, 40.4 , p. 562-72.

Polykandriotis, E. et al., (2009), Regression and persistence: remodelling in a tissue engineered axial vascular assembly. J Cell Mol Med, 13. 10, p. 4166-75.

Polykandriotis, E. et al., (2008), The venous graft as an effector of early angiogenesis in a fibrin matrix. Microvasc Res, 75. 1, p. 25-33.

Popescu, L. M., (2011), Identification of telocytes in skeletal muscle interstitium: implication for muscle regeneration. J Cell Mol Med, 15. .

Popescu, L. M. \& Faussone-Pellegrini, M. S., TELOCYTES - A case of serendipity: the winding way from Interstitial Cells of Cajal (ICC), via Interstitial Cajal-Like Cells (ICLC) to Telocytes. J Cell Mol Med, .

Riboldi, S. A. et al., (2005), Electrospun degradable polyesterurethane membranes: potential scaffolds for skeletal muscle tissue engineering. Biomaterials, 26. 22, p. 4606-15.

Roche, R., Festy, F. \& Fritel, X., (2009), Stem cells for stress urinary incontinence: the adipose promise. J Cell Mol Med, .

Rossignol, J. et al., (2009), Mesenchymal stem cells induce a weak immune response in the rat striatum after allo or xenotransplantation. J Cell Mol Med, .

Sahoo, S. et al., Growth factor delivery through electrospun nanofibers in scaffolds for tissue engineering applications. J Biomed Mater Res A, 93. 4, p. 1539-50. 
Salerno, M. S. et al., (2009), Akirin1 (Mighty), a novel promyogenic factor regulates muscle regeneration and cell chemotaxis. Exp Cell Res, 315. 12, p. 2012-21.

Sarkar, S. et al., (2008), Fabrication of a layered microstructured polycaprolactone construct for 3-D tissue engineering. J Biomater Sci Polym Ed, 19. 10, p. 1347-62.

Satija, N. K. et al., (2009), Mesenchymal stem cell-based therapy: a new paradigm in regenerative medicine. J Cell Mol Med, 13. 11-12, p. 4385-402.

Sato, K. et al., (2003), Improvement of muscle healing through enhancement of muscle regeneration and prevention of fibrosis. Muscle Nerve, 28. 3, p. 365-72.

Schnell, E. et al., (2007), Guidance of glial cell migration and axonal growth on electrospun nanofibers of poly-epsilon-caprolactone and a collagen/poly-epsilon-caprolactone blend. Biomaterials, 28. 19, p. 3012-25.

Schoof, H. et al., (2001), Control of pore structure and size in freeze-dried collagen sponges. J Biomed Mater Res, 58. 4, p. 352-7.

Seale, P. et al., (2000), Pax7 is required for the specification of myogenic satellite cells. Cell, 102. 6, p. 777-86.

Sell, S. A. et al., (2009), Electrospinning of collagen/biopolymers for regenerative medicine and cardiovascular tissue engineering. Adv Drug Deliv Rev, 61. 12, p. 1007-19.

Sill, T. J. \& von Recum, H. A., (2008), Electrospinning: applications in drug delivery and tissue engineering. Biomaterials, 29. 13, p. 1989-2006.

Snow, M. H., (1977), Myogenic cell formation in regenerating rat skeletal muscle injured by mincing. I. A fine structural study. Anat Rec, 188. 2, p. 181-99.

Soong, H. K. \& Kenyon, K. R., (1984), Adverse reactions to virgin silk sutures in cataract surgery. Ophthalmology, 91. 5, p. 479-83.

Stern-Straeter, J. et al., (2005), Impact of electrical stimulation on three-dimensional myoblast cultures - a real-time RT-PCR study. J Cell Mol Med, 9. 4, p. 883-92.

Strohman, R. C. et al., (1990), Myogenesis and histogenesis of skeletal muscle on flexible membranes in vitro. In Vitro Cell Dev Biol, 26. 2, p. 201-8.

Suciu, L. et al., Telocytes in human term placenta: morphology and phenotype. Cells Tissues Organs, 192. 5, p. 325-39.

Sze, S. K. et al., (2007), Elucidating the secretion proteome of human embryonic stem cellderived mesenchymal stem cells. Mol Cell Proteomics, 6. 10, p. 1680-9.

Telemeco, T. A. et al., (2005), Regulation of cellular infiltration into tissue engineering scaffolds composed of submicron diameter fibrils produced by electrospinning. Acta Biomater, 1. 4, p. 377-85.

Ten Broek, R. W., Grefte, S. \& Von den Hoff, J. W., Regulatory factors and cell populations involved in skeletal muscle regeneration. J Cell Physiol, 224. 1, p. 7-16.

Terzis, J. K. \& Konofaos, P., (2008), Nerve transfers in facial palsy. Facial Plast Surg, 24. 2, p. 177-93.

Terzis, J. K. \& Noah, M. E., (1997), Analysis of 100 cases of free-muscle transplantation for facial paralysis. Plast Reconstr Surg, 99. 7, p. 1905-21.

Unger, R. E. et al., The rapid anastomosis between prevascularized networks on silk fibroin scaffolds generated in vitro with cocultures of human microvascular endothelial and osteoblast cells and the host vasculature. Biomaterials, 31. 27, p. 6959-67.

van Tienen, T. G. et al., (2002), Tissue ingrowth and degradation of two biodegradable porous polymers with different porosities and pore sizes. Biomaterials, 23. 8, p. 1731-8.

Vandenburgh, H., High-content drug screening with engineered musculoskeletal tissues. Tissue Eng Part B Rev, 16. 1, p. 55-64. 
Vandenburgh, H. et al., (2009), Automated drug screening with contractile muscle tissue engineered from dystrophic myoblasts. FASEB J, 23. 10, p. 3325-34.

Vandenburgh, H. H. \& Karlisch, P., (1989), Longitudinal growth of skeletal myotubes in vitro in a new horizontal mechanical cell stimulator. In Vitro Cell Dev Biol, 25. 7, p. 607-16.

Vandenburgh, H. H., Karlisch, P. \& Farr, L., (1988), Maintenance of highly contractile tissuecultured avian skeletal myotubes in collagen gel. In Vitro Cell Dev Biol, 24. 3, p. 166-74.

Vournakis, J. N. et al., (2008), Poly-N-acetyl glucosamine nanofibers regulate endothelial cell movement and angiogenesis: dependency on integrin activation of Ets1. J Vasc Res, 45. 3, p. 222-32.

Wang, F. et al., (2009), Fabrication and characterization of prosurvival growth factor releasing, anisotropic scaffolds for enhanced mesenchymal stem cell survival/growth and orientation. Biomacromolecules, 10. 9, p. 2609-18.

Wang, G. et al., Electrospun PLGA-silk fibroin-collagen nanofibrous scaffolds for nerve tissue engineering. In Vitro Cell Dev Biol Anim, 47. 3, p. 234-40.

Wang, Y. et al., (2008), In vivo degradation of three-dimensional silk fibroin scaffolds. Biomaterials, 29. 24-25, p. 3415-28.

Weintraub, H. et al., (1991), The myoD gene family: nodal point during specification of the muscle cell lineage. Science, 251. 4995, p. 761-6.

Wilson, S. J. \& Harris, A. J., (1993), Formation of myotubes in aneural rat muscles. Dev Biol, 156. 2, p. 509-18.

Witzemann, V., (2006), Development of the neuromuscular junction. Cell Tissue Res, 326. 2, p. 263-71.

Yaffe, D., (1968), Retention of differentiation potentialities during prolonged cultivation of myogenic cells. Proc Natl Acad Sci U S A, 61. 2, p. 477-83.

Yancopoulos, G. D. et al., (2000), Vascular-specific growth factors and blood vessel formation. Nature, 407. 6801, p. 242-8.

Yang, F. et al., Genetic engineering of human stem cells for enhanced angiogenesis using biodegradable polymeric nanoparticles. Proc Natl Acad Sci U S A, 107. 8, p. 3317-22.

Ye, L. et al., Nanoparticle based delivery of hypoxia-regulated VEGF transgene system combined with myoblast engraftment for myocardial repair. Biomaterials, 32. 9, p. 2424-31.

Zammit, P. S., Partridge, T. A. \& Yablonka-Reuveni, Z., (2006), The skeletal muscle satellite cell: the stem cell that came in from the cold. J Histochem Cytochem, 54. 11, p. 1177-91.

Zhang, H. \& Hollister, S., (2009), Comparison of bone marrow stromal cell behaviors on poly(caprolactone) with or without surface modification: studies on cell adhesion, survival and proliferation. J Biomater Sci Polym Ed, 20. 14, p. 1975-93.

Zhang, Y. Z. et al., (2005), Characterization of the surface biocompatibility of the electrospun PCL-collagen nanofibers using fibroblasts. Biomacromolecules, 6. 5, p. 2583-9.

Zhao, C. et al., (2003), Structural characterization and artificial fiber formation of Bombyx mori silk fibroin in hexafluoro-iso-propanol solvent system. Biopolymers, 69. 2, p. 253-9.

Zhou, J. et al., Electrospinning of silk fibroin and collagen for vascular tissue engineering. Int J Biol Macromol, 47. 4, p. 514-9.

Zhu, Y. et al., (2008), Adipose-derived stem cell: a better stem cell than BMSC. Cell Biochem Funct, 26. 6, p. 664-75.

Zisch, A. H., Lutolf, M. P. \& Hubbell, J. A., (2003), Biopolymeric delivery matrices for angiogenic growth factors. Cardiovasc Pathol, 12. 6, p. 295-310. 


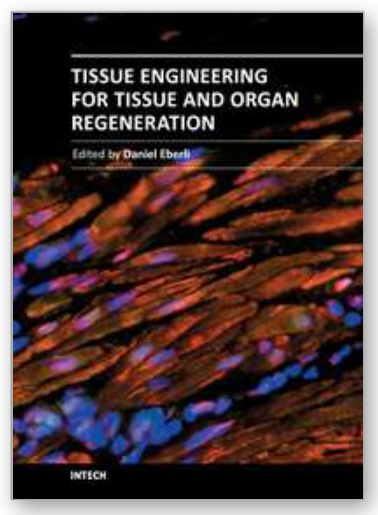

\author{
Tissue Engineering for Tissue and Organ Regeneration \\ Edited by Prof. Daniel Eberli
}

ISBN 978-953-307-688-1

Hard cover, 454 pages

Publisher InTech

Published online 17, August, 2011

Published in print edition August, 2011

Tissue Engineering may offer new treatment alternatives for organ replacement or repair deteriorated organs. Among the clinical applications of Tissue Engineering are the production of artificial skin for burn patients, tissue engineered trachea, cartilage for knee-replacement procedures, urinary bladder replacement, urethra substitutes and cellular therapies for the treatment of urinary incontinence. The Tissue Engineering approach has major advantages over traditional organ transplantation and circumvents the problem of organ shortage. Tissues reconstructed from readily available biopsy material induce only minimal or no immunogenicity when reimplanted in the patient. This book is aimed at anyone interested in the application of Tissue Engineering in different organ systems. It offers insights into a wide variety of strategies applying the principles of Tissue Engineering to tissue and organ regeneration.

\title{
How to reference
}

In order to correctly reference this scholarly work, feel free to copy and paste the following:

Klumpp Dorothee, Horch Raymund E. and Beier Justus P. (2011). Tissue Engineering of Skeletal Muscle, Tissue Engineering for Tissue and Organ Regeneration, Prof. Daniel Eberli (Ed.), ISBN: 978-953-307-688-1, InTech, Available from: http://www.intechopen.com/books/tissue-engineering-for-tissue-and-organregeneration/tissue-engineering-of-skeletal-muscle

\section{INTECH}

open science | open minds

\author{
InTech Europe \\ University Campus STeP Ri \\ Slavka Krautzeka 83/A \\ 51000 Rijeka, Croatia \\ Phone: +385 (51) 770447 \\ Fax: +385 (51) 686166 \\ www.intechopen.com
}

\author{
InTech China \\ Unit 405, Office Block, Hotel Equatorial Shanghai \\ No.65, Yan An Road (West), Shanghai, 200040, China \\ 中国上海市延安西路 65 号上海国际贵都大饭店办公楼 405 单元 \\ Phone: +86-21-62489820 \\ Fax: +86-21-62489821
}


(C) 2011 The Author(s). Licensee IntechOpen. This chapter is distributed under the terms of the Creative Commons Attribution-NonCommercialShareAlike-3.0 License, which permits use, distribution and reproduction for non-commercial purposes, provided the original is properly cited and derivative works building on this content are distributed under the same license. 